\title{
Natural sealed fractures in mudrocks: a case study tied to burial history from the Barnett Shale, Fort Worth Basin, Texas, USA.
}

Author list:

Marta Gasparrini ${ }^{1}$, William Sassi ${ }^{1}$, Julia F.W. Gale ${ }^{2}$

${ }^{1}$ IFP Energies nouvelles, 1 \& 4 Avenue de Bois Préau, Rueil-Malmaison, 92852, France;

marta.gasparrini@ifpen.fr, william.sassi@ifpen.fr

${ }^{2}$ Bureau of Economic Geology, The University of Texas at Austin, University Station, Box X Austin, Texas 78713-8924 (USA); julia.gale@beg.utexas.edu

Corresponding author:

Marta Gasparrini

IFP Energies nouvelles, Geology Dpt., R161

1 \& 4 Avenue de Bois-Préau, 92852 Rueil-Malmaison, France

E-mail: marta.gasparrini@ifpen.fr

Tel: +33 0147525429

Fax: +33 0147527126 


\section{Abstract}

The Mississippian Barnett Shale (Texas, USA), consisting of organic-rich shales and limestones, hosts the largest gas fields of North America. This study examines sealed fractures from core and outcrop samples of the Barnett Shale of the Fort Worth Basin and aims to: 1) characterize the phases occurring in the fractures from samples having experienced different burial histories; 2) establish a paragenetic sequence to relate the timing of fracture origin and sealing with the burial history of the basin; and 3) contribute to the understanding of the mechanisms of fracture formation in shales, including overpressure origin.

Four fracture generations were distinguished in the most deeply buried core samples by characterizing the sealing minerals petrographically and geochemically. The generations were inserted into the framework of a reconstructed burial history for the Fort Worth Basin, which allowed a time sequence for fracture development to be established. This in turn allowed inference of conditions of fracture development, and consideration of fracture mechanisms as well as the origin of the parent fluids of sealing minerals.

Type 1 fractures formed during early mechanical compaction (at a few 10s to 100 meters of depth) of still not fully cemented sediments. Type 2 fractures formed during moderate burial ( $2 \mathrm{~km}$ ), from slightly modified seawater. Their timing is consistent with overpressure generated during rapid deposition and differential compaction of Pennsylvanian lithologies during the onset of the Ouachita compressional event. Type 3 fractures formed during deep burial (> $3 \mathrm{~km}$ ) from silica-rich basinal brines possibly derived from clay diagenesis. Type 4 fractures formed at very deep burial ( $>4 \mathrm{~km}$ ), from hot and ${ }^{18} \mathrm{O}$-rich fluids, carrying light oil (20-30 API) and record the opening of the fluid system after hydrocarbon migration.

Differences are highlighted between the timing and thermal regimes under which fractures formed in Barnett lithologies from different areas of the basin, this suggesting that extrapolation of outcrop observations to subsurface must be used with due care. 


\section{Introduction}

Pressure prediction in basin models is strongly dependent on the permeability evolution of

tight rocks (shales, tight carbonates) that may create pressure compartments (Burrus et al., 1996; Nordgård Bolås et al., 2004). Although a vast literature exists describing natural fractures in reservoir rocks (Stearns and Friedman, 1972; Nelson, 1985; Engelder et al. 1997; Sassi et al., 2012) much less attention has been traditionally paid on fracture occurrences in shaly successions. More recently, the development of natural fractures within organic-rich shale formations has become a fertile field of investigation (Curtis, 2002; Gale et al., 2007; Engelder et al., 2009; Gale and Holder, 2010), due to the rising interest of shale exploration in unconventional gas and oil plays. The assessment of natural fracturing in shale plays is desirable for predicting prospect quality and for developing methodologies for petroleum system modeling to quantify the "fracture risk" associated with specific pressure regimes. Several processes are known to generate overpressures and consequent fracturing within these lithologies. The conversion of organic matter to hydrocarbons may increase fluid volume and induce pressure buildup (Ungerer et al., 1983; Law and Dickinson, 1985; Spencer, 1987; Barker, 1990; Burrus, et al., 1996; Fall et al., 2012). Fracturing may also be related to the imposed tectonic stress at different times of the basin history (Sibson, 2003; Evans et al., 2012) or by common diagenetic processes (Olson et al., 2009). In particular, during passive margin stages vertical loading may lead to water expulsion and disequilibrium compaction (Osborne and Swarbrick, 1997), whereas during burial, overpressure may be induced by dewatering of montmorillonite-rich clays (Powers, 1967; Bruce, 1984) and smectite to illite transformation (Freed and Peacor, 1989; Van de Kamp, 2008).

Regardless of the fracture origins, subsequent pressure release may induce mineral cementation, whose petrographic and geochemical features may help in discriminating among the different genetic mechanisms. Once the fractures are sealed, they are no longer a pathway 
for fluid-flow (Laubach, 2003). However, the cement host rock interfaces are commonly weaker than the intact host rock, and may provide planes of weakness that reactivate, which in turn can affect hydraulic stimulations of shales (Gale and Holder, 2010; Walton and McLennan, 2013). Understanding the timing, burial depth and genetic mechanism for natural fracture creation in shales, as well as the nature of the fluids precipitating the sealing minerals may therefore be relevant in basin and reservoir studies that aim to predict the distribution of fracture patterns and the consequent evolution of porosity/permeability through time. Recent works addressed to such issues in fractured reservoirs (i.e. Ficher et al., 2009; Fitz-Diaz et al. 2011; Barbier et al., 2012; Evans et al., 2012; Beaudoin et al., 2014). A few studies focusing on petrography and geochemistry of mineralized fractures in shales also exist (i.e. Al-Aasm et al., 1992; Evans, 1995; Budai et al., 2002; Michaels, 2011; Pommer et al., 2013): they mainly focus on fluid characterization issues (temperature, salinity, isotope composition, hydrocarbon types), and to a lesser extent on fracture timing with respect to the host rock burial history. The Mississippian Barnett Shale from the Fort Worth Basin (FWB; Texas, USA), consisting of organic-rich shales and limestones, hosts the largest gas fields of North America (Montgomery et al., 2005; Pollastro, 2007). Previous studies characterized fractures from the Barnett Shale in terms of orientation, size, aperture and mechanic properties (Bowker, 2003; Gale et al., 2007). In this contribution we present a study of sealed fractures from the Barnett Shale of the Fort Worth Basin which aims to: 1) Characterize the phases occurring in mineralized fractures (veins) from samples having experienced different burial histories; 2) Establish a paragenesis to relate the timing of fracture formation and cement sealing with the burial history of the basin; 3) Contribute to the understanding of the mechanisms causing fracture formation in shales; and 4) Discuss the potential of this kind of study for assessing "natural fracture risk" in petroleum system modeling. 
For such a target, samples of sealed fractures (veins) from both cores and outcrops were investigated using a multidisciplinary approach including macro- and micro-facies analyses, fracture cement petrography by optical, UV-light and cathodoluminescence (CL) microscopy, Fluid Inclusion (FI) microthermometry, as well as oxygen (O) and carbon (C) stable isotope analysis. Results from fracture characterization were inserted into the framework of a reconstructed burial history for the FWB, thus constraining fracture development in time and space, and allowing discussion of mechanisms of fracture formation and fluid origin.

\section{Geological setting}

The Fort Worth Basin (FWB) located in Texas (USA) represents one of several foreland basins formed during the late Paleozoic Ouachita orogeny (Walper, 1982; Thompson, 1988). It is bounded by the Bend arch, the Red River and Muenster arches, the Ouachita thrust and the Llano paleohigh (Fig. 1). The sedimentary fill in the FWB (Fig. 2) reaches a maximum thickness of about $4000 \mathrm{~m}$ along the Muenster arch.

From Cambrian to Late Devonian, the FWB sedimentation is characterized by fluvial siliciclastics to shallow marine carbonates (Turner, 1957; Burgess, 1976). Among these deposits, the Ellenburger Group carbonates formed on a broad epeiric platform, which later underwent prolonged exposure and extensive karst development (Kerans, 1988). The Mississippian (Fig. 2) is recorded by the Chappel Limestone and the Barnett Shale (359-318 Ma) which overlie the major unconformity developed on top of the Ordovician Ellenburger Group and Viola Limestone (Fig. 2). The Mississippian sediments record the transition of the passive margin towards an active margin setting and the overall flooding of the basin (Henry, 1982; McBee, 1999). These lithologies consist of shallow marine limestones (Chappel Limestone), passing laterally to outer ramp black shales (Barnett Shale). 
Following a major collision, the Pennsylvanian (Fig. 2) records the foreland evolution of the FWB (Henry, 1982; McBee, 1999) and is characterized by a dramatic increase of the sedimentation rate and progressive change from carbonate to siliciclastic lithologies. A few remnants of the Permian deposits exhibit complex facies changes from carbonate to siliciclastics. Triassic and Jurassic deposits are not preserved, whereas Cretaceous deposits correspond to the last sedimentation evidence of a major unconformity ( 130 Ma).

The Barnett Shale was thus deposited over a period of 25 Ma recording the transition from an uplifted area (Siluro-Devonian) towards a foreland (Pennsylvanian). It is thickest near the Muenster Arch (over $350 \mathrm{~m}$ ) and thins to less than $35 \mathrm{~m}$ at the Bend Arch and the Llano Uplift (Fig. 3), where sections are exposed (Grayson et al., 1991; Montgomery et al., 2005). The Barnett Shale is informally subdivided into the Lower and Upper Barnett (Fig. 3), which are separated in the North-East of the basin by the Forestburg Limestone (Fig. 3; Bowker, 2003; Montgomery et al., 2005; Pollastro et al., 2007). The Barnett Shale is mainly composed of dark silica-carbonate-rich mudstones with high organic matter content, although it can be heterogeneous with respect to the relative amounts of the different components, and facies with phosphatic and pyritic hardgrounds or eogenetic carbonate concretions are also common. Silica is mostly detrital though local silica sources were radiolarians and siliceous sponges. Carbonate content (depositional and diagenetic) is highly variable reflecting changes in source area, sea level rise and seawater chemistry. Details of the lithofacies, mineralogy, lateral facies variation, stratigraphic architecture and depositional environment are well documented in literature (Ross and Ross, 1987; Papazis, 2005; Hickey and Henk, 2007; Loucks and Ruppel, 2007; Monroe, 2007; Singh, 2008; Abouelresh and Slatt, 2012; Milliken et al., 2012). The Barnett Shale is the primary source rock for oil and gas produced from various Paleozoic reservoirs of the FWB. Present TOC ranges from 2 to 13 \% (Montgomery et al., 2005; Jarvie et al., 2007). The highest values refer to samples from the Llano Uplift, 
whereas the lowest values are recorded in the north-eastern of the basin, i.e. where the rocks are thermally immature and mature, respectively (see isoreflectance maps in Mongomery et al., 2005, Pollastro et al., 2007 and Romero-Sarmiento et al., 2013). Indeed, gas rich areas are found along the Ouachita thrust front and the central Muenster Arch $\left(\mathrm{R}_{0}>1.1 \%\right)$, whereas oilrich zones are concentrated to the north and west of the basin $\left(\mathrm{R}_{0}<1.1 \%\right)$ (Fig. 1).

The Barnett lithologies underwent multiple heating episodes during burial, including hydrothermal heating, and their burial history across the FWB was reconstructed by different authors (Jarvie et al., 2001; Montgomery et al., 2005; Ewing, 2006). According to the most recent model a rapid subsidence during the Pennsylvanian and Permian times with a maximum burial during the Triassic was followed by significant uplift and erosion during the Jurassic and Tertiary (Ewing, 2006). The main phase of hydrocarbon generation began in the Permian, before the maximum burial at the Permian-Triassic boundary, and peaked during the Triassic (Jarvie et al., 2001; Montgomery et al., 2005; Ewing, 2006; Pollastro et al., 2007).

\section{Dataset and Methods}

Natural fractures were collected from both outcrops and cored intervals of the Barnett Shale and associated lithologies from the FWB (Fig. 1 and 3). Organic maturity data and maximum burial depths for the sampled locations are known from literature (Mongomery et al., 2005, Pollastro et al. 2007; Moretti et al. 2012; Romero-Sarmiento et al. 2013). Outcrop sampling was accomplished at the San Saba quarry (N3109'59.6" and W09841'24.8") from the Llano Uplift in the San Saba County (Fig. 1 and 3), where the exposed Upper Barnett Shale is immature ( $\mathrm{R}_{\mathrm{o}}$ of 0.5-0.7 \%; Fig. 1) and experienced only a moderate burial ( $\left.>2 \mathrm{~km}\right)$. Subsurface samples were collected from two cored intervals. The first core was from Well A in Hamilton County (Fig. 1 and 3), having experienced heating within the oil window $\left(\mathrm{R}_{\mathrm{o}}\right.$ of 0.7-0.9 \%; Fig. 1) and a relatively deep burial (>3 km); samples were collected from the 
Lower and Upper Barnett Shale as well as the underlying Ellenburger Group carbonates. The second core was from the United Texas 1 Blakely well in Wise County (Fig. 1 and 3) having experienced deeper burial ( $>4 \mathrm{~km})$, and heating within the oil-gas window $\left(\mathrm{R}_{\mathrm{o}}\right.$ of $0.9-1.2 \%$;

Fig. 1), since it was closer to the basin depocentre and to the structures related to the Ouachita thrust belt loading (Fig. 1 and 3). Here the sampled lithologies include the Lower and Upper Barnett as well as the Forestburg Limestone.

Thin sections (30-35 $\mu \mathrm{m}$ thick) were prepared for conventional and cathodoluminescence (CL) microscopy. Thin section petrography was done on a Nikon ECLIPSE LV100 POL. The device used for cold CL is a Technosyn 8200 Mark II (OPEA). Double-polished thick sections (100-120 $\mu$ m thick) were prepared for Fluid Inclusion (FI) petrography and microthermometry. Different FI assemblages were distinguished based on their location within the crystals, e.g. crystal cores, growth zones, along trails, isolated. Microthermometry was carried out with a Linkam MDS 600 stage, calibrated with synthetic FIs and mounted on a Nikon LV100 Eclipse, with a 100 W Mercury vapor lamp which allowed UV-light observations. The Linksys 32 software enabled all the operations for FI microthermometry. The measurement accuracy was of 1 and $0.2^{\circ} \mathrm{C}$ for heating and cooling runs, respectively. In order to avoid including in the dataset homogenization temperatures $\left(T_{\mathrm{h}}\right)$ from stretched or reequilibrated FIs, especially in soft minerals like calcite, heating runs were accomplished before cooling runs and only inclusions within the same field of view were measured in order to record any sudden change in liquid/vapor ratios due to deformation. Furthermore, $T_{\mathrm{h}}$ measurements (always to liquid) were repeated twice when temperatures diverged from those acquired in the same FI assemblage. The data were discarded from the dataset if the second measurement exceeded the first by more than $5^{\circ} \mathrm{C}$. Salinities were calculated from final melting of ice $\left(\mathrm{Tm}_{\mathrm{i}}\right)$ in the binary $\mathrm{H}_{2} \mathrm{O}-\mathrm{NaCl}$ system (Bodnar, 1993). Monophase aqueous FIs were stretched to artificially nucleate a vapor bubble which allowed 
ice melting measurements $\left(T \mathrm{~m}_{\mathrm{i}}\right)$. Oil density was qualitatively estimated from fluorescence color of hydrocarbon FIs based on the conversion chart from McLimans (1987).

Carbonate powders were extracted from polished rock slabs by means of a dental drill. They were reacted with $100 \%$ phosphoric acid at $70{ }^{\circ} \mathrm{C}$ up to 7 hours for calcite samples and 36 hours for dolomite samples. A Gasbench II connected to a Thermo Finnigan Five Plus mass spectrometer was used. All values for carbonate phases are here reported in per mil relative to V-PDB by assigning a $\delta^{18} \mathrm{O}$ value of $-2.20 \%$ and a $\delta^{13} \mathrm{C}$ value of $+1.95 \%$ to the NBS19 standard. Reproducibility was checked by replicate analysis and is better than $\pm 0.05 \%$ for

$\delta^{18} \mathrm{O}$ and $\pm 0.06 \%$ for $\delta^{13} \mathrm{C}$. Oxygen isotope values of dolomite were corrected for phosphoric acid fractionation by using the factor given by Rosenbaum and Sheppard (1986).

Basin modeling was accomplished with the software TemisFlow ${ }^{\circledR}$ from Beicip-Franlab. The basin structural evolution was reconstructed using backstripping techniques together with compaction, pressure and thermal maturation data. Temperature was computed using heat flow at the base of the sedimentary pile, adjusted to match public Rock-Eval and vitrinite reflectance data. The model from Ewing (2006) was taken into account to reconstruct the FWB burial history (for details see Moretti et al., 2012 and Romero-Sarmiento et al., 2013).

\section{Macroscopic observations}

Fractures are commonly described and distinguished using the concept of sets, with orientation being an important property in defining the sets. In this study fracture orientation is not known in the cores (Table 1) so that sets cannot easily be defined or compared. We therefore use the term 'types' to indicate fractures with common morphological and sealing characteristics but with unknown orientation character. In some cases there is more than one set (orientation) for a given type. We use the term 'generations' in the interpretation section to 
refer to fractures formed due to different mechanisms at different times. Different generations of fractures are distinguished using isotope composition and FI data tied to burial history.

\subsection{Fractures from the San Saba quarry (San Saba County)}

The Upper Barnett Shale cropping out at the San Saba quarry accounts for 11 meters of section, transitional towards the top to the Marble Falls limestones and consists of weathered mudrocks with carbonate concretions and limestone beds. The stratigraphy of the section is reported in Singh (2008), whereas details on the collected samples are in Table 1. Two marker beds are recognized: a lower gray-colored phosphatic zone and a yellowish to greenish glauconitic zone. The latter marks the transition to the overlying Marble Falls limestones (see arrow in Fig. 4A). In the more carbonate-rich layers, syn-sedimentary to early diagenetic cementation formed lenticular carbonate concretions up to $5 \mathrm{~cm}$ thick, representing more resistive intervals compared with the shaly facies (Day-Stirrat et al., 2008). Two main groups of mineralized fractures were distinguished based on sealing minerals: calcite and gypsum. The less common calcite-filled fractures (Fig. 4B) are concentrated in the more carbonate-rich facies of the succession (carbonate concretions and shell debris, according to the macro- and micro-facies analysis). Different sets with variable orientation are recognized both on the quarry floor and in the wall. At the southeast side of the quarry, two sets of calcite-sealed fractures with mutually crosscutting relationships, making them broadly synchronous, were sampled. One set is oriented $118^{\circ} / 86^{\circ} \mathrm{S}$ (sample BS1) and the other is oriented $053^{\circ} / 90^{\circ}$ (sample BS3). The more common gypsum-filled fractures (Fig. 4C) postdate the calcite-filled ones, occur in the most clay rich facies (siliceous shale, according to the macro- and micro-facies analysis) and are best developed at the southeastern end of the quarry. Two main sets were recognized with mutually crosscutting relationships; the most common is shallow dipping and almost parallel to bedding $\left(100^{\circ} / 15^{\circ} \mathrm{N}\right.$; sample BS5), 
whereas the less common is sub-vertical with strike N065 (sample BS6) or high-angle with strike N070 to N120.

\subsection{Fractures from Well A core (Hamilton County)}

Macro-facies analysis of the Well A vertical core (66 m long, from the uppermost Ellenburger Group to the lowermost Marble Falls) together with micro-facies analysis of 30 thin sections allowed distinction of ten different lithofacies (Rohais and Gasparrini, 2011; Rohais et al., 2013). About 60 Rock-Eval pyrolysis analyses were made by Moretti et al. (2012). The samples investigated in this study (Table 1) include a variety of lithofacies such as massive dolomites from the basal Ellenburger Group (Fig. 5A), laminated shales with minor carbonate components, black laminated mudstones to packstones with carbonate concretions and skeletal debris packstones (Fig. 5B). Most fractures are filled by calcite (locally with minor silica) and are commonly sub-vertical and locally high-angle $\left(70-80^{\circ}\right)$ with respect to bedding. Their vertical persistence varies from few $\mathrm{cm}$ to several $\mathrm{dm}$.

\subsection{Fractures from the Blakely core (Wise County)}

The sedimentology, stratigraphy and microfacies analysis of the Blakely core is described in Loucks and Ruppel (2007). The fracture samples are hosted by either the lenticular carbonate concretions from the uppermost Lower Barnett (Fig. 5C) or by the Forestburg shaly limestones intercalated between the Lower and the Upper Barnett (Fig. 5D). The fractures are steeply dipping to vertical and bedding is horizontal. In the Forestburg Limestone the fractures are vertically continuous over several dm, whereas in the concretions they are confined within carbonate lenses up to $5 \mathrm{~cm}$ thick. The samples collected for this study are described in Table 1. The core is not oriented, and although the dominant fracture set in the 
region established in the nearby Mitchell Energy 2 T.P. Sims core is NE-SW, Gale et al., (2007) demonstrated that there are two non-parallel (interfracture angle 20-30²), calcite-filled fracture sets in the Forestburg Limestone in the Blakely core, speculating that these might be related to the two broadly north-south trending sets seen in dolostones in the T.P. Sims core. In any case the orientation of the fractures in the Blakely core is not known. Gale et al. (2007) noted a range of apertures of $<0.05-0.95 \mathrm{~mm}$ and height up to $68 \mathrm{~cm}$ for fractures in the Forestburg.

\section{Thin section Petrography}

\subsection{San Saba quarry and Well A core samples}

In the samples from the San Saba quarry and the Well A core three main types of sealed fractures were petrographically distinguished (Fig. 6). These are:

1) Fractures filled by fibrous to granular calcite (Fig. 6A). They are mostly less than $300 \mu \mathrm{m}$ thick and propagate through the sample only for a few $\mathrm{cm}$. They have a ptygmatic form (Ramsay and Huber, 1987), with axial planes lying broadly in the plane of bedding. In some places limbs are disconnected at bedding planes.

2) Fractures filled by either granular or blocky calcite crystals. Locally, when hosted by facies rich in siliceous organisms (sponges, radiolarians) a microcrystalline silica phase pre-dates the calcite in the fracture (Fig. 6B). These calcite-filled fractures display a sharp contact with the host rock and a uniform and dull red CL color (Fig. 6C and D).

3) The gypsum-filled fractures from the San Saba quarry (Fig. 4C) consist of fibrous crystals locally with an antitaxial arrangement (Fig. 6E and F), suggesting that they formed under dilation contemporaneous with mineral precipitation. 
The calcite-filled fractures with ptygmatic folds (Fig. 6A) are interpreted as being formed in still not fully compacted sediments during shallow burial. In this case the competence contrast between the filled fracture (calcite) and the host rock would have been very high, in keeping with formation of ptygmatic folds (Ramsay and Huber, 1987). These fractures could not be further investigated by FI microthermometry owing to the small crystal size.

The calcite-filled fractures with planar, sharp geometries (Fig. 6B and C) are interpreted as being formed during burial, after the main phase of mechanical compaction. The dull red uniform CL of this calcite is interpreted as typical of burial phases (Grover and Read, 1983; Dorobek, 1987). Dull luminescence occurs where reduced (bivalent) Mn and Fe are both present in the fluid and uniform; unzoned CL also points to relatively stable fluid composition during mineral growth. Minor microcrystalline silica (Fig. 6B), predating some of the calcite, likely derived from diagenetic remobilization from the silica-rich host sediments (Hesse 1990; DeMaster 2004).

The gypsum fractures in outcrop (Fig. 4C, 6A and B) were formed possibly during the uplift and consequent erosion of the overlying succession. Indeed, erosional unroofing and consequent pressure release are known to induce diffuse fracturing of sedimentary piles (Haxby and Turcotte, 1976; Xu et al., 2011). Circulation of oxidizing fluids through the pyrite-bearing shales can result in precipitation of gypsum because when pyrite is oxidized, $\mathrm{SO}_{4}{ }^{2-}$ is liberated and can react with calcium carbonates to precipitate sulphates (Joeckel et al., 2005). The dominance of low-angle gypsum fractures (Fig. 4C) is consistent with formation at shallow depth, where vertical stress due to overburden is low. Finally, the gypsum fractures were not recorded in any of the studied cores from the sub-surface, this suggesting an origin by pressure release during uplift, which could be recorded only in the southernmost part of the basin. 


\subsection{Blakely core samples}

Different fracture sealing cements were petrographically distinguished based on crystal habit, growth features, as well as CL and UV-light features. This approach allowed separation of the sealed fractures into four different types.

1) Fractures with ptygmatic folds were recognized also in the Blakely core samples. The fold envelopes are mainly oriented perpendicular to the bedding and taper towards the tips (Fig. 7A). They share similar petrographic features with those recorded in the two other locations (Fig. 6A), suggesting an origin from early mechanical compaction within not fully cemented sediments (Ramsay and Huber, 1987). Locally, calcite is fibrous with antitaxial growth, suggesting that fracture opening and mineral precipitation occurred simultaneously.

2) Sub-vertical planar fractures with sharp contacts between the sealing calcite and the host rock are common. Different calcite textures are represented within the fracture, forming bands parallel to each other and the fracture walls (Fig. 7B). They differ by calcite crystal size (from microcrystalline to granular to blocky) and fluid inclusion (FI) abundance, underlined by the alternation of cloudy (FI-rich) and clear (FI-poor) bands (Fig. 7B). The extinction is dominantly straight. Crystals elongated normal to the fracture plane (with growth controlled by the fracture opening) may show sweeping extinction. A uniform dull red to nonluminescent CL characterizes the crystals suggesting precipitation of the different calcite bands from fluids with similar geochemistry. The bands are evidence of repeated fracture opening events progressively sealed by calcite (crack-seal textures; Ramsay, 1980; Laubach, 2003). The calcite cement may therefore be considered as synkinematic, since crack-seal textures form as cement precipitates during progressive fracture widening. Calcite was slightly post-dated by or co-precipitated with pseudo-octahedric pyrite crystals possibly derived from remobilization of the syn-sedimentary framboidal pyrite which may be abundant in the Barnett Shale. 
3) A third group of fractures contain large, non-fluorescent and non-luminescent macroquartz (equant to elongated crystals larger than $20 \mu \mathrm{m}$ ) with abundant trails of fluids inclusions (Fig. 7C). The contact with the host may be lined by sub-euhedral pyrite crystals. Framboidal to euheudral smaller pyrite crystals are also found scattered within the host rock (Fig. 7D). The large pyrite crystals within the fracture are post-dated by the quartz. The pyrite within the fracture possibly resulted from Fe and S mobilization and reprecipitation during burial. Some quartz crystals contain primary inclusions related to crystal growth and others have trails of pseudosecondary FIs with the same orientation.

4) These fractures are filled only by calcite crystals displaying sharp contact with the host rock. Some open space may be left in the fracture centre. Two to three bands of calcite oriented parallel to fracture walls (Fig. 7E and F) indicate that fractures opened incrementally and were subsequently sealed by calcite (i.e. crack-seal mechanism; Ramsay, 1980). The absence of repeated crack-seal textures in the fracture centre, where larger blocky crystals occur, does not prove that fractures did not continue widening incrementally. Indeed, when opening is faster than growth, the crystals grow as in a free fluid with corresponding microtextures (Lander et al., 2008; Olson et al., 2009). Similar dull CL colors among the different calcite bands (including the one in the fracture centre) suggest that they were precipitated from a common fluid, possibly during continuous opening-sealing processes. Calcite crystals display straight extinction and are commonly twinned. The more cloudy ones are FI-rich (Fig. 7E). In many crystals highly green fluorescing spots are observed, representing trapped hydrocarbon FIs (Fig. 7F). 


\section{Synthesis of the macroscopic and petrographic observations}

A synthesis of the macroscopic (outcrop and cores) and petrographic observations from the three sampled locations was used to identify and group five main types of sealed fractures, named Type 1 to Type 5.

Type 1. These are sub-vertical calcite-filled fractures with ptygmatic fold structures (Fig. 6A and 7A), interpreted to be early, with deformation being related to compaction of not fully consolidated sediments. They are common in samples from the Blakely and Well A cores and observed in one outcrop sample.

Type 2. These are sub-vertical to high angle, planar, calcite-sealed fractures showing sharp contacts with the host rock. They may contain granular calcite crystals or crack-seal textures (Fig. 6C and 7B), represented by several bands of blocky calcite crystals, which are interpreted to have formed by repeated opening and sealing during burial. They occur in all of the three investigated localities.

Type 3. This sub-vertical fracture type is sealed by sub-euhedral pyrite crystals, likely remobilized from the pyrite-rich host sediments during burial diagenesis and then by large quartz crystals (Fig. 7C and D). It occurs only in the Blakely core.

Type 4. This sub-vertical fracture is filled incrementally by blocky calcite crystals in a crackseal arrangement (Fig. 7E and F), suggesting that fracturing and sealing occurred incrementally. This blocky calcite may be rich in green fluorescing oil inclusions and occurs only in the Blakely core.

Type 5. These are both sub-horizontal to low angle and sub-vertical to high angle fractures sealed by gypsum, with the sub-horizontal to low angle orientation being the most common (Fig. 4C). They are filled by fibrous gypsum crystals, locally showing antitaxial texture (Fig. 6E and F) and occur only in siliceous mudstone samples from the San Saba outcrop. 
Laubach (2003) showed that fracture sealing characteristics are commonly size-dependent. Interpretations of differences in cement texture and composition must therefore be referenced to size. In this study the aperture sizes of the fractures from the five types (Table 1) are broadly comparable. The variations in cement petrography described in this section therefore suggest different fracture types rather than variations due to different size fractions of a single population. This hypothesis was tested using stable isotope geochemistry and fluid inclusion analysis of fracture cements.

\section{Geochemistry and Fluid Inclusion (FI) study}

The results of FI microthermometry and isotope geochemistry for the different fracture sealing phases are reported in Table 2. Figure 8 illustrates the $\delta^{18} \mathrm{O}$ and $\delta^{13} \mathrm{C}$ values corresponding to the different calcite sealing fractures, their Barnett host lithologies and the dolomites from the Ellenburger Group.

\subsection{Samples from San Saba quarry and Well A core}

Burial calcites sealing Type 2 fractures from the San Saba quarry (Fig. 4B) were not suitable for FI microthermometry, the crystals being too small and turbid. In the clearer crystals only monophase aqueous FIs were observed, suggesting precipitation temperatures below $50-60{ }^{\circ} \mathrm{C}$ (Goldstein and Reynolds, 1994). The calcite $\delta^{18} \mathrm{O}$ varies between -5.1 and -5.8 \%o, whereas $\delta^{13} \mathrm{C}$ is between -3.6 and $-6.8 \%$.

Also the burial calcites sealing Type 2 fractures collected from Well A core (Fig. 6B and C) contain aqueous and monophase FIs. In some crystals primary monophase FIs were overheated to temperatures above $150{ }^{\circ} \mathrm{C}$ to induce stretching and artificial nucleation of a vapor bubble. Melting temperatures of ice $\left(\mathrm{Tm}_{\mathrm{i}}\right)$ could be measured on 15 stretched bi-phase 
FIs and suggested salinities of the calcite parent fluid between 4.0 and $5.2 \mathrm{wt} \% \mathrm{NaCl}$ eq., therefore corresponding to slightly modified seawater. The calcite $\delta^{18} \mathrm{O}$ is between -3.7 and $5.7 \%$, whereas $\delta^{13} \mathrm{C}$ is between -8.0 and $-12.8 \%$.

Primary FIs were measured also in the massive carbonates from the Ellenburger Group of Well A core (Fig. 5A and 9). The results for dolomite crystals (planar-E and nonplanar C) indicate homogenization temperatures $\left(T_{\mathrm{h}}\right)$ in the range 70 to $120^{\circ} \mathrm{C}$ with a broad mode at 90 $110^{\circ} \mathrm{C}$ (Fig. 10A). In most of these FIs the final melting of ice $\left(T \mathrm{~m}_{\mathrm{i}}\right)$ occurred under metastable conditions (abrupt melting at temperatures above the true $T \mathrm{~m}_{\mathrm{i}}$ ). Only a few true $T \mathrm{~m}_{\mathrm{i}}$ could be measured between -4.5 and $-5^{\circ} \mathrm{C}$, indicating salinities in the range 7.2 to $7.9 \mathrm{wt}$ $\% \mathrm{NaCl}$ eq. The dolomites have $\delta^{18} \mathrm{O}$ in the range -11.4 to $-11.8 \%$ and $\delta^{13} \mathrm{C}$ between -2.0 and $-2.4 \%$ o. Results for the blocky calcite plugging the intercrystalline dolomite pores indicate a mode for $T_{\mathrm{h}}$ around $120-140{ }^{\circ} \mathrm{C}$ (Fig. 10B) and a dominant mode for stable $T \mathrm{~m}_{\mathrm{i}}$ between -20 and $-24{ }^{\circ} \mathrm{C}$ (Fig. 10C), corresponding to salinities of $23-25$ wt $\% \mathrm{NaCl}$ eq. The dolomitization of the basal Ellenburger Group is important because these carbonates represent some of the reservoirs of the West Texas and FWB petroleum systems (Lee and Friedman, 1987; Kupecz and Land, 1991; Dennie, 2010). At the location of Well A core, the dolomitization likely occurred after the formation of the calcite-filled Type 2 fractures, at temperatures above $90-110{ }^{\circ} \mathrm{C}$ ( $T_{\mathrm{h}}$ represent only the FI minimum trapping temperatures). The data from the FI study and isotope geochemistry were input into the Friedman and O'Neil (1977) and Land (1983) experimentally determined equations for calculating the O isotope composition of the calcite and dolomite parent fluid, respectively (Fig. 11). The results are that the parent fluid of the calcites sealing Type 2 fractures from San Saba and Well A core samples had $\delta^{18} \mathrm{O}$ in the range -2 to $+1 \%$ and -2 to $+2 \%$ SMOW, respectively. The parent fluid $\delta^{18} \mathrm{O}$ for the Ellenburger dolomites falls between -1 and $+0.5 \%$ sMOW. A pressure correction of maximum $+10{ }^{\circ} \mathrm{C}$ could be applied to the measured $T_{\mathrm{h}}$ values; this was obtained 
by using as an upper constraint the maximum burial (exceeding $3 \mathrm{~km}$ ) experienced by the studied succession in Hamilton County. The $\delta^{18} \mathrm{O}$ ranges for the parent fluid of different mineral phases could be thus shifted by less than $1 \%$ o towards higher values if homogenization temperatures are corrected for the maximum burial pressure. Independently from the effect of pressure correction $\left(+10^{\circ} \mathrm{C}\right)$ on the temperature data, it seems that the different phases (Type 2 fracture calcite and massive dolomite) from different locations (San Saba and Well A) were precipitated from fluids, falling within the broad range of modified seawater (Fig. 11). This suggests rather fluid-interaction processes in a closed system, with no contribution from external exotic or hydrothermal fluids.

A flow of hydrothermal fluid through the Ellenburger Group, generated by the Ouachita thrusting pushing hot brines into the basin, was invoked to explain the occurrence in these lithologies of: 1) saddle dolomite from ${ }^{18} \mathrm{O}$-enriched fluids (Kupecz and Land, 1991), 2) native copper (Bowker, 2003) and 3) sulphide ores precipitated from saline brines (Dennie, 2010). The parent fluid of the Ellenburger dolomite from Well A core does not share geochemical features with these supposed hydrothermal ones, pointing instead to a "geothermal" dolomitization process (sensu Machel and Lonee, 2002) occurring during moderate burial ( $3 \mathrm{~km})$ of the succession from marine derived basinal fluids. A hydrothermal origin could be invoked only for the intercrystalline blocky calcite from the Ellenburger dolomite samples (Fig. 9 A and 10 B) that precipitated at temperatures (Fig. 10B) exceeding those of maximum burial from highly saline fluids (Fig. 10C), like those reported in literature for carbonates of proved hydrothermal origin (Dennie, 2010). Type 2 calcites from outcrop and Well A samples display moderately negative $\delta^{18} \mathrm{O}$ and $\delta^{13} \mathrm{C}$ values (Fig. 8), which fall in the same broad range recorded for the host rocks. The similarity between $\delta^{13} \mathrm{C}$ of the fracture calcites (precipitated from modified seawater) and the host rocks 
suggests rather low fluid-rock ratios and a buffer effect by the host rock isotope composition on the calcite composition.

\subsection{Samples from Blakely core}

According to the petrographic study, different types of sealed fractures exist in samples from the Blakely core (Fig. 7). This was confirmed by the FI investigation. Type 1 shallow compaction fractures were not investigated as the calcite crystals were too microcrystalline.

\subsubsection{Type 2 fractures}

Bands of blocky calcite crystals may contain continuous FI-rich zones (Fig. 7B). The FIs are primary, occurring within the cloudy bands of the crack-seal textures, in the crystal cores or along growth zones (Fig. 12A and B). More rarely they occur along trails hosted in microcracks (>10 $\mu$ m thick) and their trapping timing (secondary versus pseudo-secondary), from petrography only, was difficult to establish. Most FIs have shapes (squared to rectangular) partly controlled by crystallographic directions (crystal borders, cleavage) but oblate to elongated forms are also found. The FIs are not fluorescent under UV-light, suggesting an aqueous nature for the liquid phase. They are dominantly monophase liquid, indicating trapping temperatures below 50-60 ${ }^{\circ} \mathrm{C}$ (Goldstein and Reynolds, 1994). Rare bi-phase fluid inclusions display variable proportions of liquid and vapor suggesting that after trapping they underwent reequilibration, due to burial overheating or uplift pressure release. This hypothesis was confirmed by homogenization measurements: these FIs either did not homogenize after heating to $150{ }^{\circ} \mathrm{C}$ or the few obtained $T_{\mathrm{h}}$ values fell within a large spread of values (95 to $150{ }^{\circ} \mathrm{C}$ ). In five FIs, which appear monophase at room temperature, it was 
possible to nucleate a vapor bubble by rapid freezing and subsequent reheating. Here homogenization was between 50 and $60^{\circ} \mathrm{C}$, confirming the low temperature of fluid trapping. Low temperature runs were accomplished on bi-phase and likely reequilibrated FIs to evaluate fluid salinity. The FIs froze during the first cooling run within a very narrow temperature range $\left(-46\right.$ to $\left.-49^{\circ} \mathrm{C}\right)$. Reheating after freezing revealed common metastability affecting both $T$ e (eutectic point) and $T \mathrm{~m}_{\mathrm{i}}$. For the FIs that only showed metastable melting behavior, $T \mathrm{~m}_{\mathrm{iMET}}$ values were taken into account by considering them as the upper constraints of the real $T \mathrm{~m}_{\mathrm{i}}$. There is a good overlap between metastable melting $\left(T \mathrm{~m}_{\mathrm{iMET}}\right)$ and stable melting $\left(T \mathrm{~m}_{\mathrm{i}}\right)$ values (Fig. 12C). This fact, together with the similarity of inclusions' petrography and behavior during microthermometry, suggests that the FIs displaying stable and metastable behavior belong to the same population. $T \mathrm{~m}_{\mathrm{i}}$ ranges between -3.4 and -5.0 with a mode at $-5{ }^{\circ} \mathrm{C}$, this corresponding to a salinity ranging between 5.6 and $7.9 \mathrm{wt} \% \mathrm{NaCl}$ eq. (Fig. 12D). These values are in the salinity range of slightly modified seawater having interacted with rocks during burial. FIs along trails display $\mathrm{Tm}_{\mathrm{i}}$ of $-3.5^{\circ} \mathrm{C}$ corresponding to salinity of 5.7 wt \% $\mathrm{NaCl}$ eq., and are thus very similar to the primary FIs salinity. This similarity suggests that the micro-cracks hosting the FI trails formed during or shortly after the calcite crystal growth and were then sealed by fluids from the same system that precipitated the crystals. The calcite in Type 2 fractures displays $\delta^{18} \mathrm{O}$ and $\delta^{13} \mathrm{C}$ in the range 2.4 to $-3.0 \%$ and 1.6 to $2.1 \%$, respectively. The $\delta^{18} \mathrm{O}$ composition of the calcite parent fluid was possibly in the range 1-3 \%o SMOW (Fig. 11), pointing to marine derived fluids enriched in ${ }^{18} \mathrm{O}$ by fluid-rock interaction during burial. Calcites sealing Type 2 fractures from Blakely samples display moderately negative $\delta^{18} \mathrm{O}$ and positive $\delta^{13} \mathrm{C}$ values (Fig. 8), which fall in a similar range as for the fracture host rocks. The values for the sealing calcites overlap those of marine derived calcites depleted in ${ }^{18} \mathrm{O}$ during burial (Tucker and Wright 1990). 


\subsubsection{Type 3 fractures}

Multiple types of mono- and bi-phase FIs were recognized within the macroquartz crystals sealing Type 3 fracture: isolated and uniformly distributed (possibly primary), along pseudosecondary trails and along secondary trails (Fig. 13). They show no fluorescence under UVlight. Oblate to elongated shapes dominate although rectangular and crystallographic controlled shapes are also observed.

In primary and pseudo-secondary assemblages both monophase and bi-phase FIs coexist. The vapor to liquid ratio (degree of fill) measured from screen images for the largest bi-phase FIs is quite consistent (range 0.84-0.94 and mode 0.92). Bi-phase FIs may show metastability of the vapor phase after homogenization, which is overcome by freezing and then reheating them to room temperature. This observation allows interpretion of the monophase FIs as biphase FIs where the vapor bubble is metastably absent at room temperature. Measured $T_{\mathrm{h}}$ in biphase FIs fall within the range $80-120^{\circ} \mathrm{C}$, with mode at $90-100{ }^{\circ} \mathrm{C}$ (Fig. 13C). Inclusions with higher $T_{\mathrm{h}}$ were the result of reequilibration.

During cooling runs both primary and pseudo-secondary FIs froze between -46 and $-50{ }^{\circ} \mathrm{C}$. During re-heating a first liquid was observed on one inclusion at $T<-20^{\circ} \mathrm{C}$. The ice final melting showed both stable and metastable behaviors. $T \mathrm{~m}_{\mathrm{i}}$ occurred between -2.9 and $-5.6{ }^{\circ} \mathrm{C}$ with mode at $-5^{\circ} \mathrm{C}$ (Fig. 13D) corresponding to a salinity of 4.8 to $8.7 \mathrm{wt} \% \mathrm{NaCl}$ eq. (mode is 8). The values point to basinal brines up to 3 times more saline than normal seawater. In conclusion, compared to the calcite in Type 2 fractures, higher temperatures and salinities were recorded in the macroquartz from Type 3 fractures, which likely formed at greater depth from marine pore fluids having interacted longer time with the ambient rocks. According to this interpretation the system was still not in communication with external or exotic fluids. 


\subsubsection{Type 4 fractures}

The Type 4 sealed fracture used for microthermometric analysis consists of two subsequent fracturing-sealing events (Fig. 14A), the former given by clear and FI-poor calcite and the latter given by cloudy FI-rich blocky calcite crystals. Most FIs are bi-phase liquid-rich with negative crystal to squared shapes controlled by crystallographic growth directions and can be considered as primary. UV-light observation revealed that in most FIs the liquid phase is a green fluorescing oil (Fig. 14C) with 20-30 API (McLimans, 1987).

High temperature measurements were conducted on primary oil FIs. They revealed a distribution of $T_{\mathrm{h}}$ values betweeb 90 and $120^{\circ} \mathrm{C}$ with mode around $110-120^{\circ} \mathrm{C}$ (Fig. 14D). Aqueous fluid possibly coexisting with oil in these FIs could not be revealed during low temperature runs and correspondent salinity could not be determined. Coeval aqueous biphase FIs could not be investigated due to their small size and the the oil composition could not be characterized. Therefore the measured Th in primary oil FIs cannot be corrected for pressure and suggest only minimum values for FI trapping and calcite precipitation. The calcite of Type 4 fracture has $\delta^{18} \mathrm{O}$ and $\delta^{13} \mathrm{C}$ of $-9.4 \%$ and $-14.2 \%$, respectively. The $\delta^{18} \mathrm{O}$ composition of the calcite parent fluid was thus somewhat higher than 3-4 \%o SMOW (Fig. 11). The calcite sealing Type 4 fracture from Blakely displays strongly negative $\delta^{18} \mathrm{O}$ and $\delta^{13} \mathrm{C}$ values (Fig. 8), in contrast with the fracture host rock. The values for the sealing calcite are in agreement with precipitation from high temperature fluids carrying hydrocarbons with abundant light ${ }^{12} \mathrm{C}$ from organic matter degradation (Anderson and Arthur, 1983; Tucker and Wright 1990), like those reported from calcite sealing fractures of demonstrated affinity with oxidized hydrocarbon fluids, coexisting in the host rock pore spaces together with aqueous fluids at the time of the calcite precipitation (see Beaudoin et al., 2014 and Ferket et al., 2011 among the others). 


\section{Fracture paragenesis and reservoir property evolution}

The fracture paragenesis reconstructed for the studied samples from the Blakely core (Fig. 15) is composed of successive diagenetic steps from 1 to 4 . In the samples from the San Saba quarry (San Saba County) and the Well A core (Hamilton County) only the first two steps (early compaction Type 1 and crack-seal Type 2 calcite-filled fractures) were recorded. In the quarry samples late gypsum-filled fractures were also recognized (Fig. 4C) and recorded uplift pressure release and circulation of oxidizing fluids. It seems that the Type 1 and 2 fracturing recorded in these two southern locations (San Saba and Hamilton Counties) was related to early mechanical compaction during burial, possibly with an overprint of compressive stress during the early phase of the Ouachita orogeny as the foreland basin developed. Additionally, in the basal part of the Well A core (Ellenburger Group) burial dolomites formed at temperatures above $100-110{ }^{\circ} \mathrm{C}$ from slightly modified seawater $\left(\delta^{18} \mathrm{O}\right.$ from -1 to 1 \% SMOW) and post-dated the Type 2 fractures, which instead formed at temperatures below $50-60{ }^{\circ} \mathrm{C}$.

In the Blakely core, the first step (Fig. 15) is represented by mechanical compaction fractures (Type 1, Fig. 7A), filled with fibrous (locally with antitaxial arrangement) to granular calcite crystals and possibly formed during very shallow burial (few tens to one hundred meters of depth), when the sediments were still partially unconsolidated and not fully cemented. The most likely cause of early fracturing in the Barnett Shale was syn-sedimentary tectonic destabilization of the basin. The mineralizing fluid was seawater trapped within the shale pore system. The role of these fractures in enhancing vertical permeability can be considered negligible as the calcite precipitated contemporaneously with the fracture opening and the fracture vertical persistence amounted to only few $\mathrm{cm}$.

The second diagenetic step (Fig. 15) is represented by the formation of fractures filled with blocky calcite by a crack-seal mechanism indicating several fracture opening events followed 
by cementation (Type 2, Fig. 7B). The geochemical analysis indicates precipitation from fluids cooler than $50-60{ }^{\circ} \mathrm{C}$, with salinities between 5.6 and $7.9 \mathrm{wt} \% \mathrm{NaCl}$ eq. (Fig. 12) and $\delta^{18} \mathrm{O}$ in the range 1-3 \% SMOW (Fig. 11), possibly corresponding to connate seawater that became enriched in salts during water-rock interaction at depths. The vertical permeability enhancement associated with this fracturing event was not long-lasting as successive steps of fracture opening were followed by the precipitation of a new calcite band.

The third diagenetic step (Fig. 15) is given by the formation of fractures filled by pyrite, followed by macroquartz (Type 3, Fig. 7C and D) at temperatures above $90-100{ }^{\circ} \mathrm{C}$. There is no control on crystal shape during fracture opening (antitaxial or crack-seal textures are not observed) and the quartz does not form bridges as described in some tight gas sandstones (e.g. Becker et al., 2010; Fall et al., 2012). Rather, the quartz forms a continuous fill, overgrowing pyrite, although most of the quartz crystals display planes of pseudo-secondary inclusions.

(Fig. 13). The pseudo-secondary inclusion planes may indicate limited syn-growth deformation, but the lack of extensive crack-seal texture suggests that quartz cement precipitation in these fractures occurred towards the end of fracture opening. The implication is that the quartz did not only precipitate into a passive, open fracture, but formed a complete seal towards the end of fracture opening, with a few crack-seal events, meaning there was just a temporary enhancement of vertical porosity.

The fourth diagenetic step is represented by two events: the former (4a in Fig. 15) was the migration of oil which followed organic matter maturation and the latter (4b in Fig. 15) was the formation of blocky calcite fractures (Type 4, Fig. 7E and F) possibly precipitating from fluids hotter than $110{ }^{\circ} \mathrm{C}$ (Fig. 14) and with $\delta^{18} \mathrm{O}$ higher than 3-4 \%o SMOW (Fig. 11), containing light oil (20-30 API) and suggesting the opening of the system to external fluids. The creation or reactivation of this last fracture generation is therefore strictly related to organic matter maturation and hydrocarbon expulsion in the basin, a process known to induce 
pressure buildup (Ungerer et al., 1983; Law and Dickinson, 1985; Spencer, 1987; Barker, 1990; Burrus, et al., 1996; Fall et al., 2012). These fractures may remain open in the centre, possibly causing a permanent vertical permeability enhancement.

\section{Fracture timing and burial history (Blakely core)}

The data on fracturing-sealing phenomena recorded from the Blakely core samples were used to estimate their timing with respect to the burial history of the basin, considering the precipitation of the fracture sealing minerals to be in thermal equilibrium with the host rock. A burial curve for the Blakely core was extracted (Fig.16) from the 3D basin model reconstructed for the FWB (Moretti et al., 2012; Romero-Sarmiento et al., 2013). Beside the compaction fractures (Type 1), formed during the early burial history, depth and timing of the three other fracture generations (Types 2, 3 and 4) was constrained by converting modal values of homogenization temperatures (Th) for the different sealing minerals into depth, according to a geothermal gradient of $30^{\circ} \mathrm{C} / \mathrm{km}$ (from Ball and Perry, 1996). A geologically coherent maximum pressure correction in hydrostatic conditions could be added to these $T \mathrm{~h}$ mode values in order to cover the full range of possible precipitation temperatures. For minerals sealing Type 2 and Type 3 fractures a maximum pressure correction of $15^{\circ} \mathrm{C}$ could be applied. For the oil bearing calcite sealing Type 4 fracture the same approach cannot be used: a maximum pressure correction cannot be calculated as the composition of the oil is unknown and microthermometry data could not be acquired for coeval aqueous inclusions. Here only minimum temperature and depth for fracture formation and sealing can be inferred. Using this approach, fractures of Type 2 formed at a depth between 1800 and 2300 m during the Pennsylvanian time of fast subsidence and sedimentation (Fig. 16B). This could correspond to the fast deposition of the overlying Bend Group and the onset of the Ouachita thrust compression causing rapid foredeep subsidence (Ewing, 2006). In such settings 
disequilibrium compaction may generate overpressure, which may cause fracturing (i.e. Osborne and Swarbrick, 1997).

The quartz in Type 3 fracture formed between 3100 and $3600 \mathrm{~m}$ of depth, during the Early Permian (Fig. 16B). The dominant quartz mineralogy suggests liberation of silica from clay diagenesis possibly from the smectite to illite transformation, whose reaction releases water and $\mathrm{SiO}_{2}$ and which may have also accounted for increased fluid pressure in the rocks (Freed and Peacor, 1989; Van de Kamp, 2008).

For Type 4 calcite-filled fractures it can be inferred only that they formed deeper than $3900 \mathrm{~m}$ (Fig. 16B) and were pre-dated by organic matter maturation and light oil (20-30 API) migration, as witnessed by the presence of primary oil inclusions within the calcite crystals (Fig. 16B). These data are in line with the timing and depths inferred for the main Barnett oil generation phase during the Permian time (Montgomery et al., 2005; Ewing, 2006). Recent studies of sealed fractures within the Barnett Shale of the Delaware Basin, in west Texas, revealed four different fracturing-sealing events (Gale et al., 2010). Here the Barnett succession is from a mature area (maximum burial is more than $4500 \mathrm{~m}$ ) and experienced multiple episodes of overpressuring (Sinclair, 2007). Beside early compacted fractures, the timing and the type of sealing minerals of the later fractures are different from those of the Blakely core. In the Delaware basin most late fractures are cemented by quartz and/or barite, oil inclusions are blue fluorescing, this indicating lighter API, and secondary oil cracking to gas was also recorded. It is interesting to note that the second diagenetic step (Fig. 15 and 16) corresponding to crack-seal calcite-filled fractures generated during disequilibrium compaction (Type 2) was not recorded in the Barnett Shale from the Delaware Basin (Gale et al., 2010). The second fracturing event reported by these authors consists of several subhorizontal and irregular barite filled fractures with hydrocarbons (blue UV-color) formed at temperatures between 80 and $180{ }^{\circ} \mathrm{C}$ (depths between 2200 and $3500 \mathrm{~m}$ ). 
It could be argued in both cases that the burial history reconstructions from the cores are subject to error, and that because the fractures are mostly sub-vertical there is little chance of intersecting all the fracture generations present in a single vertical well core. However, the differences recorded between the two basins could also arise from differences in maximum burial depths, sedimentation and subsidence rates, compressive stress due to the proximity of fold- and thrust-belts and the deformation response to these factors, as well as the type of organic matter. Indeed, depending on the kerogen composition catagenesis may occur at different temperatures thus causing differential timing in hydrocarbon generation and consequent fracturing (i.e. Sinclair, 2007; Ali, 2009).

\section{Implication for basin modeling}

Petroleum system analysis is performed using basin modeling software that provide numerical methods to reconstruct the past geometry and the thermal history of a sedimentary basin (Ungerer et al., 1990). According to the type and quantity of organic matter in the source rocks, the timing, type and amount of hydrocarbons generated, expelled, migrated and trapped in reservoir rocks have to be computed (Béhar and Jarvie, 2013). For shale gas resources assessment basin models can be used to quantify the amount of gas in place. Performing this task means computing the non-expelled part of generated hydrocarbons in the source rock, which is partly stored as adsorbed molecules. Implementation of adsorption processes has recently been integrated in basin modeling workflows (Romero-Sarmiento et al., 2013) using the FWB case study. However, prediction of pressure build up and fracturing related to overpressure remains a challenge for basin modeling and requires calibration of specific porosity-permeability laws for low permeability shales. For such lithologies there is no similar relationship to the Kozeny-Carman law used for granular materials (Ungerer et al., 1990). Indeed the mathematical formulation of the rock porosity-permeability relationships 
must be properly calibrated on the basis of background data such as laboratory experiments on shaly rock samples (Yang and Aplin, 2010).

When fracturing occurs, important changes may result in the bulk rock reservoir properties: the development of fracture porosity and permeability has to be taken into account at the basin scale, as it may turn a closed system into an open one that will remain active until mineral precipitation seals the fractures.

Knowledge of the timing for the successive fracturing events and associated overpressures that occurred in the Barnett Shale during the burial history together with knowledge of the fluid types involved in fracture sealing, bring crucial constraints for validation of geological scenarios for the FWB evolution using the TemisFlow integrated basin modeling application. In a complementary work phase (Sassi et al., 2013) the prediction of overpressure generation and the impact of fracturing has been discussed by making use of the findings of this study. Temperature and pressure conditions prevailing for each event of the fracture paragenesis had to be retrieved in the modeled burial history of the FWB, in which these physical quantities were computed numerically. The key issue here was to highlight how the permeability law of Yang and Aplin (2010), dedicated to mudstone and depending on the relative amount of clay content, could predict two out of the five identified overpressure-fracturing events, in comparison to one overpressure-fracturing event when adopting the Kozeny-Carman law. The mudstone porosity-permeability law clearly predicts the overpressuring and corresponding fracturing events related to disequilibrium compaction (Type 2 fractures) and hydrocarbon generation (Type 4 fracture). The petrographic and geochemical characterization of sealed fractures could thus facilitate understanding of basin-scale geological evolution and the distribution and evolution of physical quantities (such as porosity and permeability) and thereby provide an improved methodology to study the impact of fluid pressure and fracturing on the distribution of ultimate gas in place within the Barnett source rock. 


\section{Conclusions}

Different types of mineralized fractures were distinguished in the Mississippian Barnett Shale samples from the investigated locations: San Saba quarry outcrops (maximum burial $>2 \mathrm{~km}$, $\mathrm{R}_{0}$ of 0.5-0.7\%), Well A core (maximum burial $>3 \mathrm{~km}, \mathrm{R}_{0}$ of 0.7-0.9 \%) and Blakely core (maximum burial $>4 \mathrm{~km}, \mathrm{R}_{0}$ of $0.9-1.2 \%$ ).

Fractures from the San Saba quarry and Well A core record mainly early compaction and moderate overburden overpressures, in line with the minor burial undergone and the major distance from the Ouachita thrust front. In San Saba also fractures related to pressure release during uplift were recorded. On the other hand, four fracture generations (from Type 1 to Type 4) were distinguished in the Blakely core, which recorded a much deeper burial and was closer to the compressive structures related to the Ouachita thrust front. Type 1 formed during early mechanical compaction (at few 10s to 100 meters of depth) of still not fully cemented sediments. Type 2 formed during moderate burial ( $2 \mathrm{~km})$, from slightly modified seawater, and could correspond to the fast deposition of the Pennsylvanian lithologies during the onset of the Ouachita compression, the most likely mechanism for overpressuring being disequilibrium compaction. Type 3 formed during deep burial (> $3 \mathrm{~km}$ ) from silica-rich basinal brines, suggesting liberation of Si possibly due to clay compaction and/or smectite to illite transformation. Type 4 formed at very deep burial ( $>4 \mathrm{~km})$, from hot and ${ }^{18} \mathrm{O}$-rich fluids, carrying light oil (20-30 API) and recorded the opening of the fluid system after organic matter maturation and hydrocarbon migration.

Vertical sealed fractures possibly due to Pennsylvanian sedimentation (Type 2) and clay diagenesis (Type 3) suggest overpressuring events with only a temporary increase in vertical permeability before hydrocarbon generation and consequent fracturing occurred (Type 4). Differences are highlighted between the timing and thermal regimes under which fractures 
formed in Barnett lithologies experiencing different burial histories, this suggesting that extrapolation of outcrop observations to subsurface must be used with due care.

The Barnett fracturing-sealing history reconstructed from the Fort Worth Basin (this study) differs from the one reconstructed for the Delaware Basin (Gale et al., 2010) suggesting that differences in maximum burial depths, proximity with thrust fronts and type and distribution of the organic matter within the sediments are among the parameters which could explain the differences recorded between these two basins.

This study on natural fractures furnished relative timing of fracture-sealing episodes in terms of depth and temperature. This information may be instrumental in allowing basin modeling applications to assign more realistic information on shale permeability evolution through time and to study the impact of fracturing on the remaining gas in place in the source rock.

\section{Acknowledgements}

The work on natural sealed fractures from the Barnett Shale of the Fort Worth Basin was performed in the framework of the GASH consortium. I. Moretti, L. Milelli, S. Rohais, J.M. Daniel and M. Ducros from IFPEN provided connections, stimulated discussions and helped with the sampling of the Well A core.

We acknowledge the Bureau of Economic Geology (University of Texas at Austin) for material from the Blakely core.

We are grateful to the Prof. M. Joachimski (Geozentrum Nordbayern) for the carbonate isotope analysis and especially for the tightly scheduled replicates of dolomite samples. The guest editor O. Lacombe, the reviewer N. Beaudoin and an anonymous reviewer are thanked for their careful revision, which allowed improvement of the manuscript. 


\section{References}

Abouelresh, M.O., Slatt, R.M., 2012. Lithofacies and sequence stratigraphy of the Barnett Shale in east-central Fort Worth Basin, Texas. AAPG Bulletin 96 (1), 1-22.

Al-Aasm, I.S., Muir, I., Morad S., 1995. Diagenetic conditions of fibrous calcite vein formation in black shales: petrographic, chemical and isotopic evidence. Bulletin of Canadian Petroleum Geology 41 (1), 46-56.

Ali, W.A., 2009. Lithofacies, depositional environment, burial history and calculation of organic richness from wireline logs: A study of Barnett Shale in the Delaware Basin, Pecos Co., West Texas, and comparison with the Barnett Shale in the Fort Worth Basin.

Unpublished M.S. thesis, The University of Texas at Austin, 231 pp.

Anderson, T.F., Arthur, M.A., 1983. Stable isotopes of oxygen and carbon and their application to sedimentologic and paleoenvironmental problems. In: Erthur, M.A. (Ed.), Stable isotopes in sedimentary geology. SEPM Short Course No. 10, Tulsa, Oklahoma, 151 pp.

Ball M.M., Perry, W. J., 1996. Bend Arch-Fort Worth Basin Province (045). In: Gautier D.L., Dolton G.L., Takahashi K.I., Varnes K.L. (Eds.), National assessment of United States oil and gas resources - Results, methodology, and supporting data. U.S. Geological Survey Digital Data Series DDS-30, Release 2, [CD-ROM].

Barbier M., Leprêtre R., Callot J.P., Gasparrini M., Daniel J.M., Hamon Y., Lacombe O., Floquet M., 2012. Impact of fracture stratigraphy on the paleo-hydrogeology of the Madison Limestone in two basement-involved folds in the Bighorn basin, (Wyoming, USA). Tectonophysics 576-577, 116-132.

Barker, C., 1990. Calculated volume and pressure changes during the thermal cracking of oil to gas in reservoirs. AAPG Bulletin 74 (8), 1254-1261. 
Beaudoin N., Bellahsen N., Lacombe O., Emmanuel L., Pironon J., 2014. Crustal-scale fluid flow during the tectonic evolution of the Bighorn Basin (Wyoming, USA). Basin Research. doi: 10.1111/bre.12032

Béhar, F., Jarvie, D., 2013. Compositional modeling of gas Generation from two shale gas resource systems: Barnett Shale (United States) and Posidonia Shale (Germany). In: Chatellier J., Jarvie, D. (Eds.), Critical assessment of shale resource plays. AAPG Hedberg 5, pp. 25-44.

Bodnar, R.J., 1993. Revised equation and table for determining the freezing point depression of H2O-NaCl solutions. Geochimica and Cosmochimica Acta 57, 683-684.

Bowker, K. A., 2003. Recent development of the Barnett Shale play, Fort Worth Basin: West Texas. Geological Society Bulletin 42 (6), 4-11.

Bruce, C.H., 1984. Smectite dehydration-Its relation to structural development and hydrocarbon accumulation in northern Gulf of Mexico basin. AAPG Bulletin 68, 6, 673-683.

Budai, J.M., Martini, A.M., Walter, L.M., Ku, T.C.W, 2002. Fracture-fill calcite as a record of microbial methanogenesis and fluid migration: a case study from the Devonian Antrim Shale, Michigan Basin. Geofluids 2, 163-183.

Burgess, W.J., 1976. Geologic evolution of mid-continent and Gulf Coast areas; plate tectonics view. Gulf Coast Association of Geological Societies Transactions 26, 132-143.

Burrus, J., Osadetz, K., Wolf, S., Doligez, B., Visser, K. and Dearborn, D., 1996. A two-dimensional regional basin model of Williston basin hydrocarbon systems. AAPG Bulletin 80 (2), 265-291.

Curtis, J.B., 2002. Fractured shale-gas systems. AAPG Bulletin 86 (11), 1921-1938.

Day-Stirrat, R.J., Loucks, R.G., Milliken, K.L., Hillier, S., van der Pluijm, B.A., 2008. Phyllosilicate orientation demonstrates early timing of compactional stabilization in calcite- 
cemented concretions in the Barnett Shale (Late Mississippian), Fort Worth Basin, Texas (U.S.A.). Sedimentary Geology 28, 27-35.

DeMaster, D.J., 2004. In: MacKenzie, F.T. (Ed.), Sediments, diagenesis and sedimentary rocks. Treatise on Geochemistry, Vol. 7 (Holland, H.D., Turekian, K.K. series Eds.), Elsevier, New York, pp. 87-98.

Dennie, D., 2010. An integrated paleomagnetic and diagenetic investigation of the Barnett Shale and underlying Ellenburger Group carbonates, Fort Worth Basin, Texas. Unpublished Ph.D. thesis, University of Oklahoma, 210 pp.

Dorobek, S.L., 1987. Petrography, geochemistry, and origin of burial diagenetic facies, Siluro-Devonian Helderberg Group (Carbonate Rocks), Central Appalachians. AAPG bulletin $71(5), 492-514$.

Engelder, T., Gross, M.R., Pinkerton, P., 1997. An analysis of joint development in thick sandstone beds of the Elk Basin anticline, Montana-Wyoming. In: Hoak, T.E., Klawitter, A.L., Blomquist, P.K. (Eds.), Fractured Reservoirs: Characterization and Modeling: Rocky Mountain Association of Geologists Guidebook, pp. 1-18.

Engelder, T., Lash, G.G., Uzcategui, R.S., 2009. Joint sets that enhance production from Middle and Upper Devonian gas shales of the Appalachian Basin. AAPG Bulletin 93 (7), 857-889.

Evans, M.A., 1995. Fluid inclusions in veins from the Middle Devonian shales: Arecord of deformation conditions and fluid evolution in the Appalachian Plateau. Geological Society of America Bulletin, 107 (3), 327-339.

Evans, M.A., Bebout, G.E., Bown, C.H., 2012. Changing fluid conditions during folding: an example from the central Appalachians. Tectonophysics 576-577, 99-115. 
Ewing, T., 2006. Mississippian Barnett Shale, Fort Worth basin, north-central Texas: Gas-shale play with multi-trillion cubic foot potential: Discussion. AAPG Bulletin 90 (6), 963-966.

Fall, A., Eichhubl, P., Cumella, S.P., Bodnar, R.J., Laubach, S.E., Becker, S.P., 2012. Testing the basin-centered gas accumulation model using fluid inclusion observations: southern Piceance Basin, Colorado. AAPG Bulletin 96 (12), 2297-2318.

Ferket, H., Guilhaumou, N., Roure, F., Swennen, R., 2011. Insights from fluid inclusions, thermal and PVT modelling for paleo-burial and thermal reconstruction of the Córdoba petroleum system (NE Mexico). Marine and Petroleum Geology 28(4), 936-958.

Freed, R.L., Peacor, D. R., 1989. Geopressured shale and sealing effect of smectite to illite transition. AAPG bulletin 73 (10), 1223-1232.

Fischer, M.P., Higuera-Diaz, I.C., Evans, M.A., Perry, E.C., Lefticariu, L., 2009. Fracture-controlled paleohydrology in a map-scale detachment fold: Insights from the analysis of fluid inclusions in calcite and quartz veins. Journal of Structural Geology 31, 1490-1510.

Fitz-Diaz, E., Hudleston, P., Siebenaller, L., Kirschner, D., Camprubi, A., Tolson, G., Pi Puig, T., 2011. Insights into fluid flow and water-rock interaction during deformation of carbonate sequences in the Mexican fold-thrust belt. Journal of Structural Geology 33, 12371253.

Gale, J.F.W., Reed, R.M., Holder, J., 2007. Natural fractures in the Barnett Shale and their importance for hydraulic fracture treatments. AAPG Bulletin 91 (4), 603-622.

Gale, J.F.W., Holder, J., 2010. Natural fractures in some US shales and their importance for gas production. Geological Society, London, Petroleum Geology Conference series, vol. 7, 1131-1140. doi: 10.1144/0071131 
Gale, J.F.W., Reed, R.M., Becker, S.P., Ali, W., 2010. Natural Fractures in the Barnett Shale in the Delaware Basin, Pecos Co. West. AAPG Annual Convention and Exhibition, Denver, Colorado. Search and Discovery Article \#10226.

Goldstein R.H., Reynolds T.J., 1994. Systematics of fluid inclusions in diagenetic minerals. SEPM Short Course 31, SEPM (Eds.), Tulsa, Oklahoma.

Grayson, R.C. Jr., Merill, G.K., Pranter, M.J., Lambert, L.L., 1991. Carboniferous geology and tectonic history of the southeastern Fort Worth (foreland) Basin and Concho platform, Texas. Dallas Geological Society, Dallas, Texas, Field Trip no. 13, 67 pp.

Grover, G., Read, J.F., 1983. Paleoaquifer and deep burial related cements defined by regional cathodoluminescent patterns, Middle Ordovician carbonates, Virginia. AAPG Bulletin 67 (8), 1275-1303.

Guo, X., He, S., Liu, K., Song, G., Wang, X., Shi, Z., 2010. Oil generation as the dominant overpressure mechanism in the Cenozoic Dongying depression, Bohai Bay Basin, China. AAPG Bulletin 94 (12), 1859-1881. doi: 10.1306/05191009179

Haxby, W.F., Turcotte, D.L., 1976. Stress induced by the addition or removal of overburden and associated thermal effects. Geology 4, 181-185.

Henry, J. D., 1982. Stratigraphy of the Barnett Shale (Mississippian) and associated reefs in the northern Fort Worth Basin. In: Martin, C.A. (Ed.), Petroleum Geology of the Fort Worth Basin and Bend Arch Area. Dallas Geological Society, pp. 157-178.

Hesse, R., 1990. Silica diagenesis: Origin of inorganic and replacement cherts. In: McIlreath, I.A., Morrow, D.W. (Eds.), Diagenesis. Geoscience Reprint Series, 4, Ottawa, pp. 253-275.

Hickey, J.J., Henk, B., 2007. Lithofacies summary of the Mississippian Barnett Shale, Mitchell 2 T.P. Sims well, Wise County, Texas. AAPG Bulletin 91 (4), 437-443. 
Hill, R.J., Jarvie, D.M., Zumberge, J., Henry, M., Pollastro, R.M., 2007. Oil and gas geochemistry and petroleum systems of the FortWorth Basin. AAPG Bulletin, 91 (4), 445473.

Jarvie, D.M., Claxton, B.L., Henk, F., Breyer, J.T., 2001. Oil and shale gas from the Barnett Shale, Ft. Worth basin, Texas. AAPG Annual Meeting Program, p. A100.

Jarvie, D.M., Hill, R.J., Ruble, T.E., Pollastro, R.M. 2007. Unconventional shale-gas systems: the Mississippian Barnett Shale of north-central Texas as one model for thermogenic shale-gas assessment. AAPG Bulletin 91 (4), 475-499.

Joeckel, R.M., Ang Clement, B.J., VanFleet Bates, L.R., 2005. Sulfate-mineral crusts from pyrite weathering and acid rock drainage in the Dakota Formation and Graneros Shale, Jefferson County, Nebraska. Chemical Geology 215, 433-452.

Kerans, C., 1988. Karst-controlled reservoir heterogeneity in Ellenburger Group carbonates of west Texas. AAPG Bulletin 72 (10), 1160-1183.

Kupecz, J.A., Land, L.S., 1990. Late-stage dolomitization of the Lower Ordovician Ellenburger Group, West Texas. Journal of Sedimentary Petrology 61 (4), 551-574.

Land, L.S.,1983. The application of stable isotopes to studies of the origin of dolomite and to problems of diagenesis of clastic sediments. In: Arthur M.A., Anderson T.F., Kaplan I.R., Veizer J., Land L.S. (Eds.), Stable Isotopes in Sedimentary Geology, SEPM Short Course, Tulsa, Oklahoma., pp. 4.1-4.22.

Lander, R.H., Larese, R.E., Bonnell, L.M., 2008. Toward more accurate quartz cement models - The importance of euhedral vs. non-euhedral growth rates. AAPG Bulletin 92 (11), 1537-1564.

Laubach, S.E., 2003. Practical approaches to identifying sealed and open fractures. AAPG Bulletin 87 (4), 561-579. 
Law, B.E., Dickinson, W.W., 1985. Conceptual model for origin of abnormally pressured gas accumulations in low-permeability reservoirs. AAPG Bulletin 69 (8), 12951304.

Lee, Y.E., Friedman, G.M., 1987. Deep-burial dolomitization in the Ordovician Ellenburger Group carbonates, west Texas and southeastern New Mexico. Journal of Sedimentary Petrology 57 (3), 544- 557.

Loucks, R.G., Ruppel, S.C., 2007. Mississippian Barnett Shale: Lithofacies and depositional setting of a deep-water shale-gas succession in the Fort Worth Basin, Texas. AAPG Bulletin 91 (4), 579-601.

Machel, H.G., Lonee, J., 2002. Hydrothermal dolomite - a product of poor definition and imagination. Sedimentary Geology 152, 163-171.

McBee, W. Jr., 1999. Regional paleo-geography and geology of the southern midcontinent. In: Grace D.T., Hinderlong G.D. (Eds.), The Permian Basin: Providing energy for the future. West Texas Geological Society Publication 99-106, pp. 139-158.

McLimans, R.K., 1987. The application of fluid inclusions to migration of oil and diagenesis in petroleum reservoirs. In: Hanor J.S., Kharaka, Y.K., Land L.S. (Eds.), Geochemistry of Waters in Deep Sedimentary Basins. Selected Contributions from the Penrose Conference. Applied Geochemistry 2, 585-603.

Michaels, J., 2012. Veins, Fluid Migration and Hydrocarbon Generation in the Utica Shale, Northern Appalachian Basin, New York. Colgate Academic Review 9, Article 12, pp. 292-315.

Milliken, K.L., Day-Stirrat, R.J., Papazis, P.K., Dohse, C., 2012. Carbonate lithologies of the Mississippian Barnett Shale, Fort Worth Basin, Texas. In: Breyer J.A. (Ed.), Shale reservoirs - Giant resources for the $21^{\text {st }}$ century. AAPG Memoir 97, pp. 290-321. 
Monroe, R.M., 2009. Petrographic and stratigraphic analysis of the Barnett Shale (Mississippian) in Hill County, Texas: Evidence for eustacy and tectonism. Unpublished M.S. thesis, Texas Christian University, 154 pp.

Montgomery S.L., Jarvie, D.M., Bowker, K.A., Pollastro, R.M., 2005. Mississippian Barnett Shale, Fort Worth Basin: North central Texas: Gas-shale play with multi-tcf potential. AAPG Bulletin 89 (2), 155-175.

Moretti, I., Romero-Sarmiento, M-F., Béhar F., Jarvie, D.M., Lorant, F., Carpentier, B., Ducros, M., Cacas, M-C., Rohais, S., Gasparrini, M., Sassi, W. (2012). GASH_2yr: Petroleum system of the Barnett Shale and source rock characteristic. IFPEN Report 62291, $152 \mathrm{pp}$

Nelson, R.A., 1985. Volume I: geologic analysis of naturally fractured reservoirs. In: Chilingar, G.V. (Ed.), Contributions in Petroleum Geology \& Engineering. Gulf Publishing Company, Book division. 320 pp.

Nordgård Bolås, H.M., Hermanrud, C., Teige, G.M.G., 2004. Origin of overpressures in shales: constraints from basin modeling. AAPG Bulletin 88 (2), 193-211.

Olson, J.E., Laubach, S.E., Lander, R.H., 2009. Natural fracture characterization in tight gas sandstones: Integrating mechanics and diagenesis. AAPG Bulletin 93 (11), 1535-1549.

Osborne, M.J., Swarbrick, R.E. 1997. Mechanisms for generating overpressure in sedimentary basins: a reevaluation. AAPG Bulletin 81 (6), 1023-1041.

Papazis, P. K., 2005. Petrographic characterization of the Barnett Shale, Fort Worth Basin, Texas. Unpublished M.S. thesis, University of Texas at Austin, Texas, 142 pp.

Pollastro, R.M., 2007. Total petroleum system assessment of undiscovered resources in the giant Barnett Shale continuous (unconventional) gas accumulation, Fort Worth Basin, Texas. AAPG Bulletin 91 (4), 551-578. 
Pommer, L., Gale, J.F.W., Eichhubl, P, Fall, A, Laubach, S.E., 2013. Using structural diagenesis to infer the timing of natural fractures in Marcellus Shale. Unconventional Resources Technology Conference, Denver, Colorado, USA. URTeC Control ID 1580135.

Powers, M.C., 1967. Fluid-release mechanisms in compacting marine mudrocks and their importance in oil exploration. AAPG Bulletin 51 (7), 1240-1254.

Pollastro, R., Jarvie, D.M., Hill, R.J., Adams, C.W., 2007. Geologic framework of the Mississippian Barnett Shale, Barnett-Paleozoic total petroleum system, Bend arch-Fort Worth Basin, Texas. AAPG Bulletin 91 (4), 405-436.

Ramsay, J. G., 1980. The crack-seal mechanism of rock deformation. Nature 284, 135139.

Ramsay, J.G., Huber, M.I. 1987. The techniques of modern structural geology. Volume 2: Folds and Fractures. Academic Press, London, pp. 309-700.

Rohais, S., Gasparrini M., 2011. GASH_2yr: Sedimentology and sequence stratigraphy of the Barnett Shale. IFPEN Report 62091, 78 pp.

Rohais, S., Gasparrini, M., Moretti, I., Daniel, J-M., 2013. Sédimentologie et architecture stratigraphique dans les argiles riches en matière organique: example des Barnett Shale, Bassin de Fort Worth (Texas). 14th ASF - Congrès Français de Sédimentologie, Paris. (abstract in French).

Romero-Sarmiento, M.-F., Ducros, M., Carpentier, B., Lorant, F., Cacas, M.-C., PegazFiornet, S., Wolf, S., Rohais, S., Moretti, I., 2013. Quantitative evaluation of TOC, organic porosity and gas retention distribution in a gas shale play using petroleum system modeling: Application to the Mississippian Barnett Shale. Marine and Petroleum Geology 45, 315-330. Rosenbaum, J., Sheppard, S.M., 1986. An isotopic study of siderites, dolomites and ankerites at high temperatures. Geochimica and Cosmochimica Acta 50, 1147-1150. 
Ross, C.A., Ross, J.R.P., 1987. Late Paleozoic sea levels and depositional sequences. In: Ross, C.A., Haman, D. (Eds.), Timing and deposition of eustatic sequences: constraints on seismic stratigraphy. Cushman Foundation for Foraminiferal Research, Special Publication 24, pp. 137-149.

Sassi, W., Guiton, M.L.E., Leroy, Y.M., Daniel, J.M., Callot, J.P., 2012. Constraints on bed scale fracture chronology with a FEM mechanical model of folding: The case of Split Mountain (Utah, USA). Tectonophysics 576-577, 197-215.

Sassi, W., Milelli, L., Gasparrini, M., 2013. Fracturing in basin models, Application to the Barnett Formation in the Fort Worth Basin, Texas. AAPG Annual Convention and Exhibition, Pittsburgh, Pennsylvania. Search and Discovery Article \#10594.

Sibson, R.H., 2003. Brittle-failure controls on maximum sustainable overpressure in different tectonic regimes. AAPG Bulletin 87 (6), 901-908.

Sinclair, T. D., 2007. The generation and continued existence of overpressure in the Delaware Basin, Texas. Unpublished Ph.D. thesis, University of Durham, UK, 302 p.p.

Singh, P., 2008. Lithofacies and sequence stratigraphic framework of the Barnett shale, northeast Texas. Unpublished Ph.D. thesis, University of Oklahoma, 181 p.p.

Spencer, C.W., 1987. Hydrocarbon generation as a mechanism for overpressuring in Rocky Mountain region. AAPG Bulletin 71 (4), 368-388.

Stearns, D.W., Friedman, M., 1972. Reservoirs in fractured rocks. AAPG Bulletin 18, 82-106.

Thompson, D.M., 1988. Fort Worth Basin. In: Sloss L.L. (Ed.), The geology of North America. Geological Society of America, vol. D-2, pp. 346-352.

Tucker, M.E., Wright, V.P., 1990. Carbonate sedimentology. K., Wiley-Blackwell Scientific Publications. 
Turner, G. L., 1957. Paleozoic stratigraphy of the Fort Worth Basin: Abilene and Fort Worth Geological Societies. 1957 Joint Field Trip Guidebook, Abilene Geological Society, Fort Worth Geological Society, pp. 57-77.

Ungerer, P., Béhar, E., Discamps, D., 1983. Tentative calculation of the overall volume expansion of organic matter during hydrocarbon genesis from geochemistry data: implications for primary migration. In: Bjoroy, M. (Ed.), Advances in organic geochemistry. Chichester, John Wiley, pp. 129-135.

Ungerer, P., Burrus, J., Doligez, B., Chenet, P.Y., Bessis, F., 1990. Basin evaluation by integrated two-dimensional modeling of heat transfer fluid flow, hydrocarbon generation and migration. AAPG Bulletin 74 (3), 309-335.

Van de Kamp, P.C., 2008. Smectite-illite-muscovite transformations, quartz dissolution, and silica release in shales. Clays and Clay Minerals 56, 66-81.

Walper, J.L., 1982. Plate tectonic evolution of the Fort Worth Basin. In: C.A. Martin, ed. Petroleum geology of the Fort Worth Basin and Bend Arch area. Dallas Geological Society, 237-251.

Walton, I., McLennan, J., 2013. The role in natural fractures in shale gas production. In: Bunger, A.P., McLennan, J., Jeffrey, R. (Eds.), Effective and Sustainable Hydraulic Fracturing. Intech, pp. 327-356. doi: 10.5772/56404

Xu, H., Tang, D., Zhang, J, Yin, W., Chen, W, 2011. Formation mechanism of underpressured reservoir in Huatugou oilfield of Qaidam basin. Journal of Earth Science 22 (5), 632-639.

Yang, Y., Aplin, A.C., 2010. A permeability-porosity relationship for mudstones. Marine and Petroleum Geology, 27 (8), 1692-1697. 


\section{Captions}

Figure 1: Regional setting, large structures, and structure contour map of the Fort Worth Basin. Contours are drawn on top of the Ordovician Ellenburger Group (contour interval is $1000 \mathrm{ft}$ (305 m), after Montgomery et al., 2005). Locations of the Barnett outcrop in San Saba County, and the two sampled wells are shown together with regional trends in vitrinite reflectance (\% $\left.\mathrm{R}_{0}\right)$ in the Lower Barnett Shale (after Romero-Sarmiento et al., 2013).

Figure 2: Generalized stratigraphic column of the Fort Worth Basin also showing the distribution of oil and gas reservoirs. The Barnett Shale is shaded dark grey and the stipple indicates the Ordovician - Mississippian section figured in the inset in Figure 3 (modified after Montgomery et al., 2005).

Figure 3: North-South geological cross section illustrating the general Fort Worth Basin stratigraphy and basin architecture (modified after Montgomery et al. 2005), and approximate locations of the studied sections (black bars). The inset is a more detailed schematic cross section (North-East to South-West approximately from Wise to San Saba Counties) of the Ordovician - Mississippian section. The extent of the cores and outcrops and their stratigraphic position are indicated by the black bars. V-S refers to Viola-Simpson interval (modified after Montgomery et al., 2005).

Figure 4: Barnett outcrops in San Saba County (Llano Uplift). A. Quarry section. The greenish layer at the top ( 30-40 cm thick; red arrow) marks the transition towards the overlying Marble Falls limestones. B. Calcite-filled fracture oriented $050^{\circ} / 90^{\circ}$ hosted by the 
more carbonate-rich facies (sample BS3). C. Photograph and line diagram of calcite-filled fractures hosted by the more shaly facies (samples BS5 and BS6).

Figure 5: Samples from the Well A and the Blakely cores. A. Massive dolomites with vuggy porosity from the Ellenburger Group (Well A, sample G5-1). B. High-angle calcite fracture developing through a carbonate shell debris facies (Well A, sample G6). C. Carbonate concretion lense from the uppermost Lower Barnett, hosting a sub-vertical fracture sealed by calcite. The fracture is confined within the carbonate concretion lense and does not propagate through the less competent shaly facies (Blakely, sample BB3). D. Forestburg Limestone hosting multiple thin calcite-sealed fractures persistent over several decimeters (Blakely, Samples B7134 and BB1).

Figure 6: Photomicrographs of cemented fractures from the San Saba quarry and Well A core. A. A thin vertically-oriented calcite-filled fracture with ptygmatic folds indicative of post-folding compaction. White lines (FATs) indicate fold axial traces subparallel to horizontal fine layering in the shale. Way up indicated. (Well A, Sample G1). Plane polarized light. B. Large blocky calcite fills a fracture in phosphatic shale facies with minor carbonate components. The calcite post-dates a silica phase with micro-crystalline texture (Well A, sample G3). Crossed polarized light. C. Sub-vertical fracture filled by granular calcite in a packstone with shell debris (Well A, sample G4). Plane polarized light. D. As for C but under CL. Note the uniform dull dark red color of the calcite fracture fill. E. Fibrous gypsum crystals with antitaxial arrangement in a sub-vertical fracture (San Saba, Sample BS6). Plane polarized light. F. As for E but in crossed polarized light. 
Figure 7: Photomicrographs of different types of sealed fractures from the Blakely core. A. Ptygmatic fold fracture filled by granular calcite which loses persistency through the Forestburg Limestone (Sample BB1). Crossed polarized light. B. Detail of calcite-filled fracture formed by successive events of crack and seal. The larger crystals are inclusion-rich (cloudy appearance). The primary fluid inclusions form continuous bands through the crystals parallel to the fracture walls (Sample BB1). Crossed polarized light. C. Macroquartz crystals with trails of FIs post-dating euhedral pyrite crystals (black) in the fracture (Sample BB3). Plane polarized light. D. Same as C in reflected light. The pyrite is golden yellow and occurs both as small framboidal crystals in the host sediment and as reprecipitated euhedral crystals in the fracture. E. Calcite-filled fracture having sharp contact with the host lithology which displays two episodes of crack-seal mechanism and blocky crystals in the centre. The cloudy appearance is due to the abundance of FIs (Sample BB2). Plane polarized light. F. Same as C but under UV-light. The calcite shows fluorescing green spots corresponding to trapped hydrocarbon FIs.

Figure 8: Cross-plot of $\delta^{18} \mathrm{O}$ versus $\delta^{13} \mathrm{C}$ values (in \%o relative to the V-PDB standard) for the studied carbonate phases: the different calcite sealing fractures, the fracture host rocks and the dolomites from the Ellenburger Group.

Figure 9: Carbonates of the Ellenburger Group from Well A core (Samples G5-1 and G5-2).

A. Mosaic of nonplanar dolomite crystals evolving towards nonplanar C crystals lining vuggy pores, at present plugged by a later intercrystalline blocky calcite cement. Plane polarized light. B. Mosaics of planar-E dolomite crystals with cloudy cores and growth zones, indicating the presence of primary FIs. C. Detail of dolomite crystal with primary FIs 
distributed along growth zones. D. Detail of isolated bi-phase FIs in a blocky intercrystalline calcite crystal.

Figure 10: Results of microthermometry for primary FIs in carbonates of the Ellenburger Group (Well A core). A. Frequency distribution of Th values for dolomite. B. Frequency distribution of $T$ h values for calcite. C. Frequency distribution of $T \mathrm{~m}_{\mathrm{i}}$ values for calcite.

Figure 11: Plot of precipitation temperature versus $\delta^{18} \mathrm{O}(\mathrm{V}-\mathrm{PDB})$ of the fracture calcites hosted in the Barnett Shale from San Saba, Well A and Blakely, and of the massive dolomite from the Ellenburger Group (Well A). The equations of Friedman and O’Neil (1977) and Land (1983) were used to calculate the $\delta^{18} \mathrm{O}$ (SMOW) of the parent fluids in equilibrium with calcites (continue black curves) and dolomites (dotted blue curves), respectively.

Figure 12: Crack-seal calcite fractures (Type 2) from Blakely core: FI petrography and microthermometry. A. FI-rich band in calcite crystals from the central part of a crack-seal fracture (Sample BB1). Plane polarized light. B. Detail of primary FIs concentrated in the calcite crystal cores. Plane polarized light. C. Frequency distribution of stable $\left(T \mathrm{~m}_{\mathrm{i}}\right)$ and metastable $\left(\mathrm{Tm}_{\mathrm{iMET}}\right)$ final melting of ice from primary aqueous FIs in calcite crystals. $\mathbf{D}$. Salinity of the same FIs calculated from the stable final melting $\left(T \mathrm{~m}_{\mathrm{i}}\right)$ values only.

Figure 13: Macroquartz sealed fracture (Type 3) from Blakely core: FI petrography and microthermometry. A. Macroquartz crystal with mono- and bi-phase aqueous FIs uniformly distributed (Sample BB3). Plane polarized light. B. Trails of pseudo-secondary FIs. Plane polarized light. C. Frequency distribution of Th. Some FIs recorded thermal reequilibration. 
D. Frequency distribution of stable $\left(T \mathrm{~m}_{\mathrm{i}}\right)$ and metastable $\left(T \mathrm{~m}_{\mathrm{iMET}}\right)$ final melting of ice from primary FIs.

Figure 14: Blocky calcite fracture (Type 4) from Blakely core: FI petrography and microthermometry. A. Detail of Type 4 fracture with two calcite opening-sealing events. The former (to the left) is given by clear inclusion-poor crystals and the latter (to the right) is given by cloudy inclusion-rich blocky crystals (Sample BB2). Plane polarized light. B. Same as A, but under UV-light. The green fluorescing spots correspond to oil FIs trapped within the blocky calcite crystals. C. Detail of primary FIs from a blocky calcite crystal under UV-light. The oil FIs are green-fluorescing. D. Frequency distribution of Th for primary oil FIs.

Figure 15: Paragenesis for the mineralized fractures reconstructed from the interpretation of the Blakely core samples. The first two diagenetic steps were recorded also in the samples from the San Saba quarry and the Well A core.

Figure 16: Burial curve extracted from the 3D basin model for the Blakely well. A. Burial curve with stratigraphic information. The Barnett Shale is represented by the green lithologies (red arrow). B. Burial curve with thermal information. The timing of the formation and sealing of the different studied fractures is indicated by the colored areas. The blue circle corresponds to Type 1 fractures. Green and yellow ellipses for Type 2 and Type 3 sealed fractures cover the full range of possible formation depths. The red circle for Type 4 fractures indicates the minimum depth of formation (Th mode value), whereas the arrow points towards the possible higher formation depths. 
Table 1: Samples investigated in this study including location, stratigraphic position, host lithology depth, fracture orientation where known, fracture type, kinematic aperture, and the mineral phase and texture of the fracture fill. Fractures in the core are subvertical or at a high angle to bedding, but as neither core was oriented fracture trend could not be established.

Table 2: Results of FI study for the different mineral phases. MP, BP and Aq stand for monophase, biphase and aqueous inclusions, respectively. Range and mode values of homogenization temperatures $(T \mathrm{~h})$, ice melting temperatures in stable $\left(T \mathrm{~m}_{\mathrm{i}}\right)$ and metastable conditions $\left(T \mathrm{~m}_{\mathrm{iMET}}\right)$ are shown. Salinity was calculated from stable $T \mathrm{~m}_{\mathrm{i}}$ only and is expressed in wt \% $\mathrm{NaCl}$ eq . Results of $\mathrm{O}$ and $\mathrm{C}$ isotope analysis for carbonate phases are also reported (in \%o relative to the V-PDB standard). 